\title{
Comparative Effects of Ethanolic Extract of Gongronema latifolium and Piper guineense on Blood Electrolytes in Ethanol Exposed Wistar Rats
}

\section{Ali Fredrick U1, Ominyi MC1, Nwankwo OVU1, Ibiam UA² and Ogbanshi ME²}

${ }^{1}$ Department of Biotechnology, Ebonyi State University, Abakaliki, Nigeria

${ }^{2}$ Department of Biochemistry, Ebonyi State University, Abakaliki, Nigeria

\begin{abstract}
Aim: The effects of ethanolic extract of Gonngronema latifolium and Piper guineense on serum electrolytes, function indices and liver marker enzymes on wistar rats exposed with ethanol were investigated.

Methology: Forty male albino rats (weighing 150-220 g) were used. The animals were divided into four groups A, B, C, and D with C and D subdivided into four subgroups; C1, C2, C3 and C4; D1, D2, D3 and D4 for G. latifolium and Piper guineense respectively, each contained four rats. Group B, and sub groups $C$ and $D$ rats were exposed with $70 \%$ ethanol for 7 days to induce liver damage and later treated group $C$ and $D$ with ethanol extracts for 21 days. The following quantities were administered orally to the albino rat per kg body weight: $200,400,600$, and $800 \mathrm{mg}$; while $0.9 \%$ normal saline was served to both the control group. The levels of serum electrolytes and liver marker enzymes were monitored in order to evaluate the protective effects of the plant extracts. The blood was collected through cardiac puncture under chloroform anesthesia after 21 days. Thereafter, the sera were analyzed to determine the status of selected blood electrolytes: sodium $(\mathrm{Na}+)$, potassium, $(\mathrm{K}+)$, calcium, zinc, bicarbonate, and biochemical indices ALT, AST, ALP and total bilirubin levels.

Results: The results showed that the level biochemical indices increased significantly $(p<0.05)$ whereas electrolytes, in negative control were significantly $(p<0.05)$ reduced compared to positive control and treated groups. A significant increase $(p<0.05)$ in $\mathrm{Na}, \mathrm{K}, \mathrm{Zn}, \mathrm{Ca}$, and $\mathrm{HCO}_{2}$ in ethanol exposed and treated groups attaining near normalization in a dose - dependent fashion in both $G$. latifolium and Piper guineense after 21 days therapy were observed. These results highlight the ability of Gongronema latifolium at high doses and Piper guineense at lower doses to ameliorate electrolytes imbalance in wistar rats exposed to ethanol by reducing liver markers towards normal and the observed effects are associated with their antioxidant activities.
\end{abstract}

Keywords: Piper guineense; Gongronema latifolium; Ethanol; Electrolytes; Serum; Liver

\section{Introduction}

Medical Herbalism, one of the primary complementary approaches to medicine in many parts of the world [1]. The use of plant extracts for treatment and prevention of diseases has shown a complete holistic framework of healing [2]. One of the basic principles of herbal medicine is that all constituents in the whole plant extract work collectively to achieve therapeutic efficacy [3]. Treatment with herbs aims to facilitate healing by influencing or stimulating the body's own innate healing capacities in a manner that is safe and effective [4]. Since they often work to support or influence balance in a particular body system, herbs can be considered to act as homeostatic agents [5].

Gongronema latifolium is called arokeke by the Yoruba and utazi by the Igbos [6] it contain phytochemical compounds including alkaloids, saponins, tannins (flavonoids), and glycosides [7]. Studies have shown that these phytochemicals found in Gongronema latifolium may influence cellular proteins with enzymic activities [8]. Tannins have been shown to be strong inhibitors of oxidative enzymes present in foodstuffs [9].

The seed and leaf extracts are capable of exhibiting a depolarizing neuromuscular activity in a concentration related manners [10]. The antiparasitic, antimicrobial and antifungal activities of the leaf and seeds of $P$. guineense have also been reported [11]. According to Iqbal, et al. [12], leaves of $P$. guineense have been used by traditional medical practitioners for the treatment of respiratory diseases and correction of female infertility problems, and the seeds as an aphrodisiac [13]. Ethanol, also called ethyl alcohol, pure alcohol, grain alcohol, or drinking alcohol, is a colourless liquid, a drug that affect the brain. It is the oldest drug used for recreation known, it causes intoxication when consumed [14]. Ethanol is also used in beverages, thermometers and as a fuel. In common usage, it is often referred to simply as alcohol [15].

In continuation of our earlier study, we examined the effects ethanol extract of G. latifolium and Piper guineense on selected blood electrolytes in ethanol exposed wistar rats.

\section{Materials and Methods}

\section{Biological materials}

The biological materials used include: Gongronema latifolium and Piper guineense, male wistar rats. The rats age 12 weeks and average weight 150-220 g were sourced from University of Nigeria Nsukka, Nigeria. It was acclimatized for seven days in the animal house Biochemistry of Department Faculty of Biological Sciences E Bonyi State University Abakaliki. They were allowed access to feed and water ad libitum and under controlled 12/12 hour light and dark cycles. The

*Corresponding author: Ali FU, Department of Biotechnology, Ebonyi State University, Abakaliki, Nigeria, Tel: +2348063893022; E-mail: alifredrick13@ gmail.com

Received: April 10, 2015; Accepted: April 30, 2015; Published May 04, 2015

Citation: Ali Fredrick U, Ominyi MC, Nwankwo OVU, Ibiam UA, Ogbanshi ME (2015) Comparative Effects of Ethanolic Extract of Gongronema latifolium and Pipe guineense on Blood Electrolytes in Ethanol Exposed Wistar Rats. Biochem Anal Biochem 4: 179. doi:10.4172/2161-1009.1000179

Copyright: (C) 2015 Ali Fredrick U, et al. This is an open-access article distributed under the terms of the Creative Commons Attribution License, which permits unrestricted use, distribution, and reproduction in any medium, provided the original author and source are credited. 
Citation: Ali Fredrick U, Ominyi MC, Nwankwo OVU, Ibiam UA, Ogbanshi ME (2015) Comparative Effects of Ethanolic Extract of Gongronema latifolium and Piper guineense on Blood Electrolytes in Ethanol Exposed Wistar Rats. Biochem Anal Biochem 4: 179. doi:10.4172/2161-1009.1000179

Page 2 of 5

plant materials were sourced from Abakpa Market in Abakaliki Local Government Ebonyi State Nigeria and authenticated by a taxonomist Professor Okafor in Biology Department Ebonyi State University Abakaliki, the voucher specimen were deposited in the herbarium section.

Equipment and reagents: The equipments and reagents employed on the course of this work were of analytical grade.

Experimental design: Forty wistar rats housed in a separate cages were used for this work. It was divided into four groups; $a, b, c$ and d. Group $\mathrm{c}$ and $\mathrm{d}$ were subdivided into four: $\mathrm{c} 1, \mathrm{c} 2, \mathrm{c} 3, \mathrm{c} 4, \mathrm{~d} 1, \mathrm{~d} 2, \mathrm{~d} 3$, and $\mathrm{d} 4$. Group b, $\mathrm{c}$ and $\mathrm{d}$ were exposed to $70 \%$, ethanol for seven days. Group c and d were further treated with graded doses: 200,400,600 and $800 \mathrm{mg} / \mathrm{kg}$ body weight of G latifolium and Piper guineense respectively for 21 days, whereas group $\mathrm{a}$ and $\mathrm{b}$ served as the positive and negative controls.

\section{Methods}

Extract preparation: The leaves of G. latifolium and Piper guineense were dried to constant weight in the laboratory at room temperature for two weeks. Thereafter it was granded with a milling machine [16]. This was further sieved with a $1 \mathrm{~mm}$ sieve size, $200 \mathrm{~g}$ was dissolved in a 4-litre percolate absolute ethanol (95\%). The system was allowed to stand for 48 hours and it was filtered with a white filter cloth. The ethanol extract was allowed to evaporate to dryness at a room temperature. The dried extract was made into aqueous solution and used for biochemical assays [17].

Evaluation of biochemical indices: The biochemical indices were evaluated using the method of Andullu et al. [18].

Analysis of blood electrolytes: Twenty four hours after the last dose administration, the animals were anaesthetized with chloroform vapour, quickly brought out of the jar and sacrificed [19]. Serum was used for electrolyte analysis. Ten microliter $(10 \mu \mathrm{L})$ of distilled water was pipette into labelled test tubes, which was used as reagent blank, $10 \mu \mathrm{L}$ of sample and, then $10 \mu \mathrm{L}$ reagent standard. Pipette $1.0 \mathrm{~mL}$ as reagent in sample blank. The serum was analyzed for electrolytes using audicom full auto electrolyte analyzer [20].

Statistical analysis: The results were expressed as mean \pm SD and tests of statistical significance were carried out-using one-way ANOVA. The statistical package used was Statistical Package for Social Sciences (SPSS for windows, version 20). Values of $\mathrm{p}<0.05$ were considered significant.

\section{Discussion}

The liver is an organ involved in many metabolic functions and is prone xenobiotic injury because of its central role in xenobiotic metabolism [21]. Administration of alcohol increased the mean value of liver marker enzymes significantly $(\mathrm{p}<0.05)$ (Figures $1-4)$. This is in agreement with Bruce RD [22]. Exposure of hepatocytes to ethanol alters the membrane structure and functions by increasing the leakage of enzymes into the circulation [23]. The results of this study show that the ethanol extract of G latifolium and Piper guineense leaf have some degree of hepatoprotective ability. Based on the results obtained it can be inferred that G latifolium and Piper guineense leaf extracts have some protective effect on the liver as shown by the reduction in the level of the liver enzymes. Herbal remedies have contain variety of chemical constituents like polyphenol, flavonoids, alkaloids, glycoside etc [24]. These are present in G. latifolium and Piper guineense and may be responsible for this effect. It can be inferred that the leaf of G. latifolium and Piper guineense have appreciable ability to prevent damage to the liver. The, total bilirubin activities were also restored. This is in consonance with the report of Dheer et al., [25].

The blood electrolytes were carried out to evaluate and monitor electrolytes imbalances. The function of the kidneys is to regulate endocrine processes such as RBC synthesis, Vitamin D secretion and blood pressure maintenance [26]. The renal system plays a primary role in the regulation of electrolyte/fluid balance, the $\mathrm{PH}$ buffer system and in the elimination of waste products [27]. When kidney function

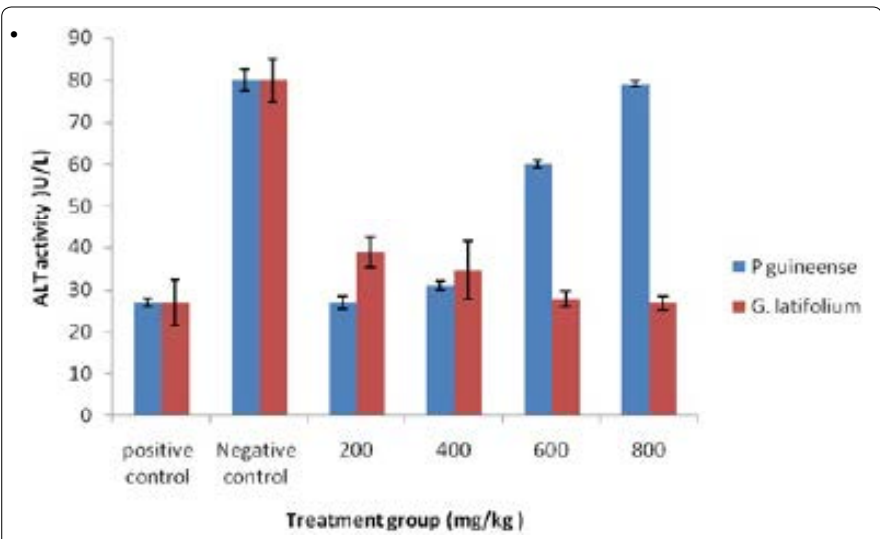

Figure 1: Effect of $P$. guineense and G. latifolium extracts on ALT activity in ethanol-exposed wistar rats.

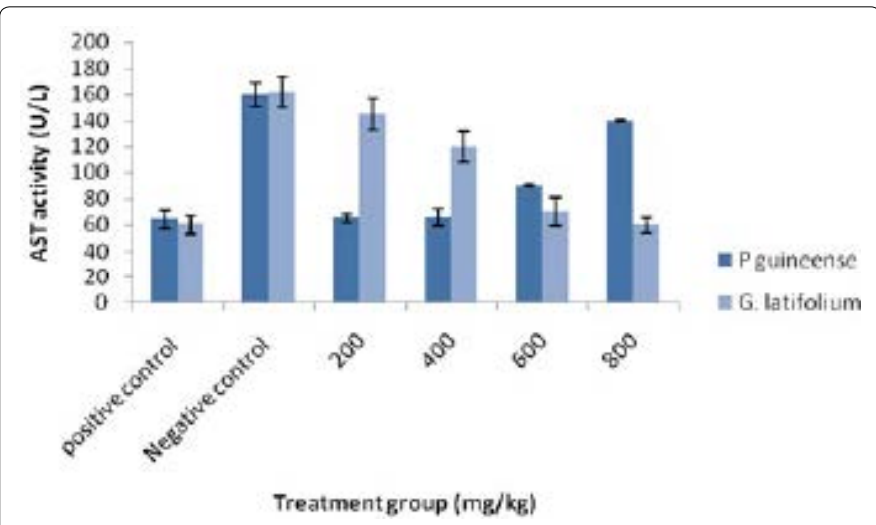

Figure 2: Effect of $P$. guineense and G. latifolium extracts on AST activity in ethanol-exposed wistar rats.

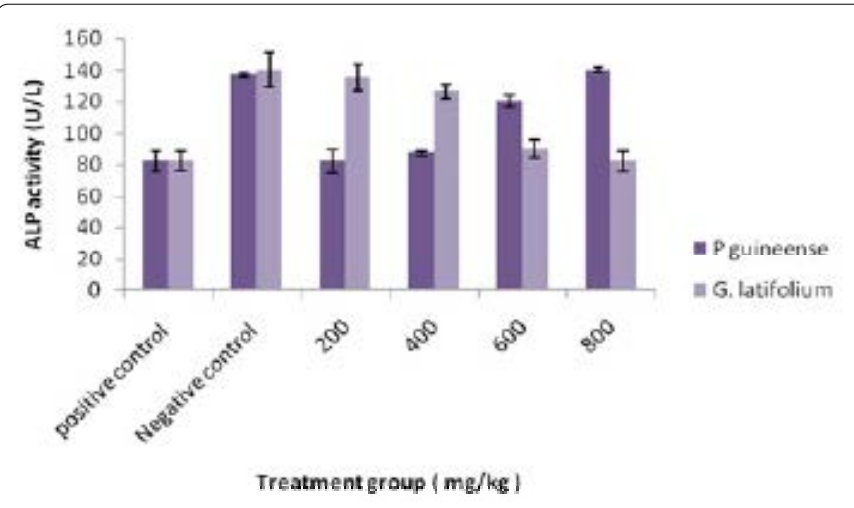

Figure 3: Effect of $P$. guineense and G. latifolium extracts on ALP activity in ethanol-intoxicated wistar rats. 
Citation: Ali Fredrick U, Ominyi MC, Nwankwo OVU, Ibiam UA, Ogbanshi ME (2015) Comparative Effects of Ethanolic Extract of Gongronema latifolium and Piper guineense on Blood Electrolytes in Ethanol Exposed Wistar Rats. Biochem Anal Biochem 4: 179. doi:10.4172/2161-1009.1000179

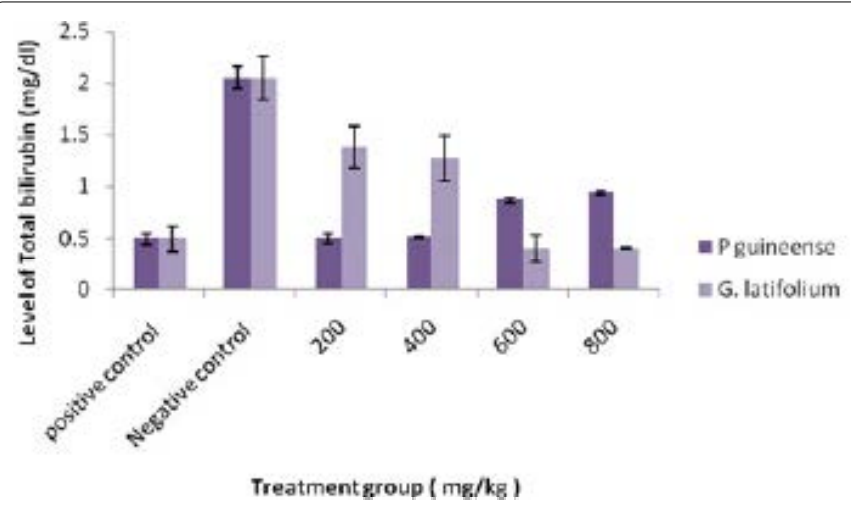

Figure 4: Effect of $P$. guineense and G. latifolium extracts on the level of total bilirubin in ethanol-intoxicated wistar rats.

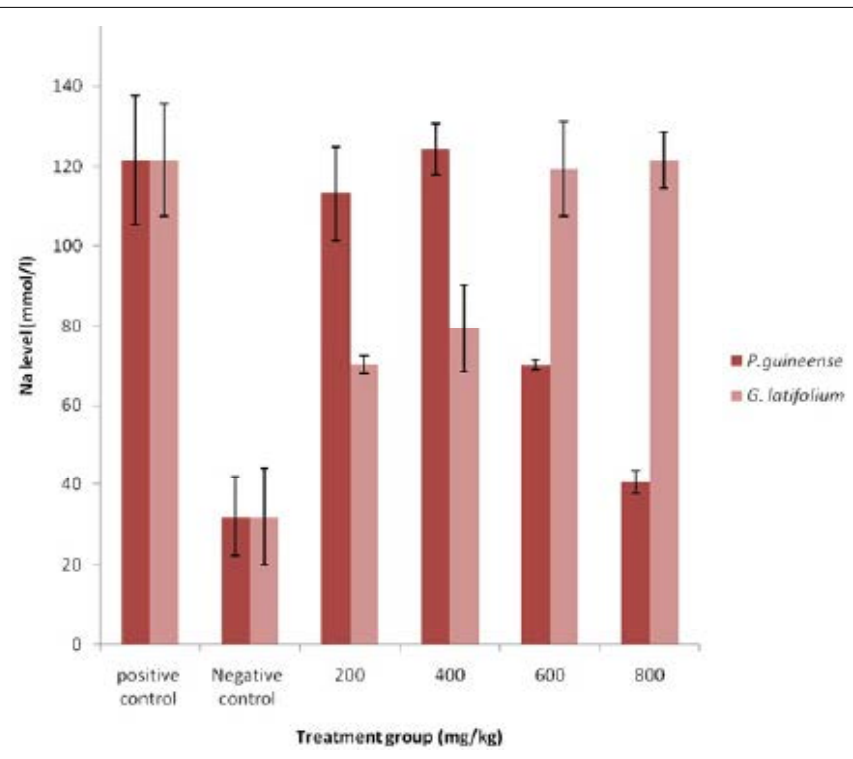

Figure 5: Effect of $P$. guineense and G. latifolium extracts on the level of blood $\mathrm{Na}$ in exposed rats. The difference in $\mathrm{Na}$ value of treated and untreated rats were significant $(P<0.05)$ when compared with treated and untreated wistar rats. The results are mean \pm SD of four rats in each group.

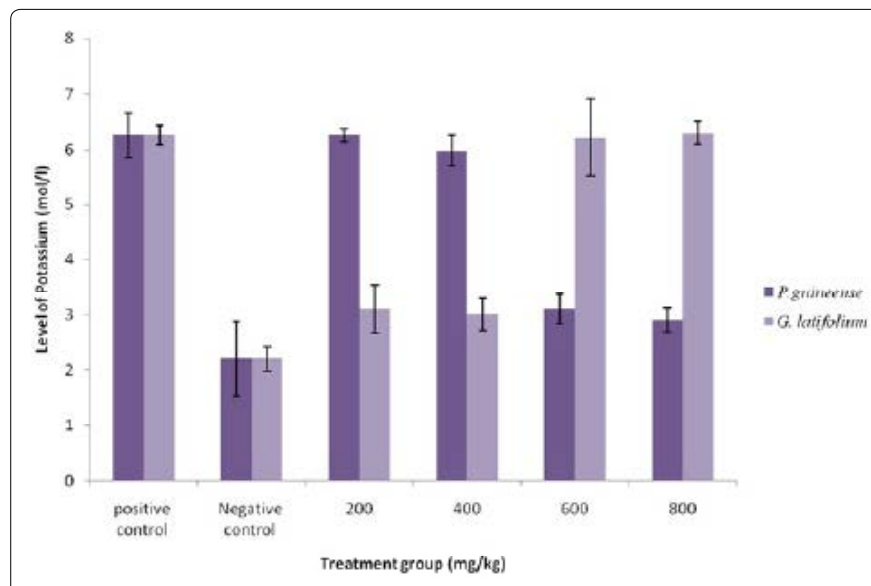

Figure 6: Effect of $P$. guineense and G. latifolium extracts on the level of blood Potassium In exposed rats. The difference in $\mathrm{K}$ value of untreated rats were significant $(P<0.05)$ decrease when compared with treated and normal wistar rats. The results are mean \pm SD of four rats in each group.

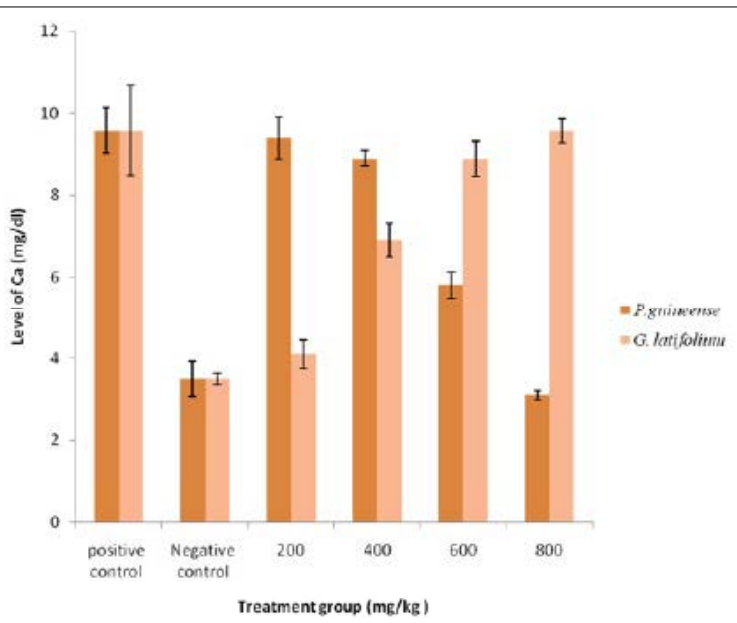

Figure 7: Effect of $P$. guineense and G. latifolium extracts on the level of blood $\mathrm{Ca}$ in ethanol -exposed wistar rats. The difference in $\mathrm{Ca}$ value of treated and untreated rats were significant $(P<0.05)$ when compared with treated and untreated wistar rats. The results are mean \pm SD of four rats in each group.

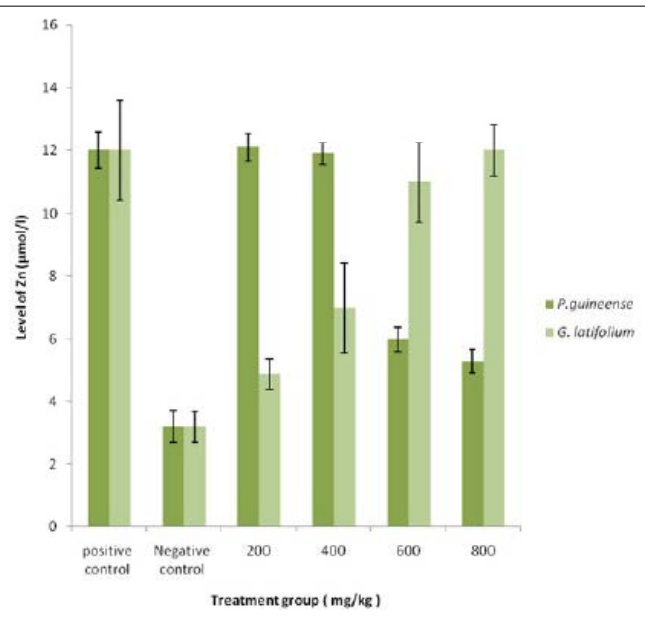

Figure 8: Effect of $P$. guineense and G. latifolium extracts on the level of blood $\mathrm{Zn}$ in ethanol -exposed wistar rats. The difference in $\mathrm{Zn}$ value of treated and untreated rats were significant $(P<0.05)$ when compared with treated and untreated wistar rats. The results are mean \pm SD of four rats in each group.

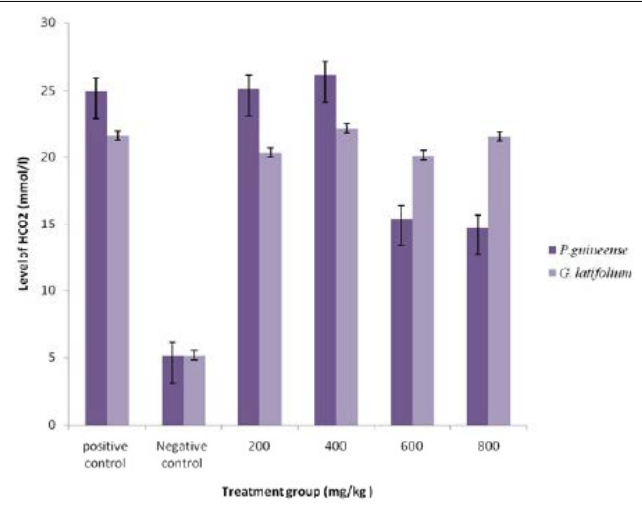

Figure 9: Effect of $P$. guineense and G. latifolium extracts on the level of blood $\mathrm{HCO}_{2}$ in ethanol -exposed albino rats. The difference in bicarbonate value of treated and untreated rats were significant $(P<0.05)$ when compared with treated and untreated wistar rats. The results are mean $\pm S D$ of four rats in each group. 
Citation: Ali Fredrick U, Ominyi MC, Nwankwo OVU, Ibiam UA, Ogbanshi ME (2015) Comparative Effects of Ethanolic Extract of Gongronema latifolium and Piper guineense on Blood Electrolytes in Ethanol Exposed Wistar Rats. Biochem Anal Biochem 4: 179. doi:10.4172/2161-1009.1000179

Page 4 of 5

declines, as a result complications of ethanol consumption obviously these processes become impaired [28]. Hence, in this study there was a significant $(\mathrm{P}<0.05)$ alteration in selected serum electrolytes in the ethanol exposed rats (Figures 5-9).

Sodium is the major positive ion in fluid outside of cells. It regulates the total amount of water in the body and the transmission of sodium into and out of individual cells also plays a role in critical body function [29]. In this study there was a significant $(\mathrm{p}<0.05)$ decrease in sodium level in ethanol exposed rats without treatment compared to group exposed and treated. The observed decrease in exposed group may be attributed to the action of ethanol on antidiuretic hormone vassopresin that is inhibited by ethanol leading to the kidney passing water direct to the bladder without reabsorbed it [30]. Hyponatremia is proposed to be due to an inappropriate production of antidiuretic hormone (vasopressin) by the leukemic cells [31]. This leads to loss of sodium, this is quite consistent with earlier reports that ethanol intoxication leads to decrease plasma levels of sodium ions [32]. The effect of extract on electrolytes of ethanol exposed and treated animals were in agreement with report by Grover, et al. [33] on effect of G. latifoliumand, Piper guineenseon ethanol intoxicated. Whereas Henry [34] also stated ethanol leads to production of reactive oxygen species conditions that can directly cause electrolyte imbalance.

Potassium was significantly $(\mathrm{P}<0.05)$ reduced in ethanol exposed groups compared to treated groups. The significant reduction in the level of potassium in ethanol exposed group showed that ethanol could lead to raised blood pressure in the users since potassium has been shown to have protective effect against hypertension [35]. $\mathrm{Na}^{+}$$\mathrm{K}^{+}$ATPase also helps in the movement of these electrolytes across the membrane and ensures that there is a balance in the system. Hence, the plant extract restored the level of $\mathrm{Na}^{+}$and $\mathrm{k}^{+}$to normal, there must be a balance between the two. If there is elevated $\mathrm{Na}$ ions which can lead to raised blood pressure and subjecting the user to risk of cardiovascular diseases [36].

Calcium is need in the body to build and fix bones and teeth, it helps nerves to work. In this study the calcium level in ethanol exposed rats decreased significantly $(\mathrm{P}<0.05)$ compared to treated and normal control. Hence, the plant extract normalize the calcium level as indicated in this study in a dose dependent fashion. Calcium is important for nerve conduction and muscular contraction thus the weakness observed in ethanol exposed animals may be attributed to decrease in calcium level. Zinc is an essential trace element for humans and other animal (Figure 8). It is found in the bone, muscles, brain kidney and liver [37]. It is one of the elements found in enzymes [38]. It decreased significantly $(\mathrm{P}<0.05)$ in ethanol exposed albino rats. Reports have shown that zinc play roles in homeostasis of normal function of brain and CNS [39]. Hence ethanol treatments have altered the homeostasis that exist in this organism. However, it may be inferred that treatment with extract of G. latifolium and Piper guineense restored blood electrolytes homeostasis altered as a result of being exposed to ethanol.

Bicarbonate is a chemical (buffer) that keep the $\mathrm{pH}$ of blood from becoming too acidic or too basic [40]. Bicarbonate test helps to evaluate and keep track of conditions that affect blood bicarbonate levels including liver, kidney and metabolic conditions [41]. A decrease in bicarbonate level in ethanol exposed rats indicates ethanol poisoning [42]. When the bicarbonate levels are higher or lower than, it suggests that the body is having trouble maintaining its acid- base balance or that their electrolyte balance has upset, perhaps by loss or retention of fluid $[43,44]$. The plant extracts have proved therapeutic efficacy by restoring the level of bicarbonate towards normal in a dose dependent manner (Figure 9).

\section{Conclusions}

Electrolytes imbalance is a common finding in complications of liver and kidney damage. The alteration in electrolyte concentration brought on by the exposure of animals to ethanol per se may be life threatening. This study inferred the need for routine measurement of serum electrolytes for ethanol consumers.

\section{References}

1. American Society for Testing and Materials (2001) Standard test method for estimating acute oral toxicity in rats. American society for testing and materials E 1163 87, Philadelphia, USA 55-62.

2. Tietz NW (1996) Fundamentals of Clinical Chemistry, Sauders, (4thed) Philadelphia 984.

3. World Health Organization WHO (1996) Guidelines for the Assessment of Herbal medicines. WHO expert committee on specification for pharmaceutical preparations. Technical Report series 863.

4. Tietz NW (1976) Fundermental of Clinical Chemistry WB saunder Co.i. Phila, PA 874.

5. Ugochukwu NH, Babady NE (2002) Antioxidant effects of Gongronema latifolium in hepatocytes of rat models of non-insulin dependent diabetes mellitus. Fitoterapia 73: 612-618.

6. Ugochukwu NH, Babady NE (2003) Antihyperglycemic effect of aqueous and ethanolic extracts of Gongronema latifolium leaves on glucose and glycogen metabolism in livers of normal and streptozotocin-induced diabetic rats. Life Sci 73: 1925-1938.

7. Ugochukwu NH, Babady NE, Cobourne M, Gasset SR (2003) The effect of Gongronema latifolium extracts on serum lipid profile and oxidative stress in hepatocytes of diabetic rats. J Biosci 28: 1-5

8. Glew RH, Vandejagt DJ, Lockett C, Grivetti LE, Smith GC, et al. (2010) Comparative evaluation of effect of plant extract on liver damage. Journal of ethnomedicine 23: 70-87.

9. Millson M (1997) Amino acid, fatty acid and mineral composition of 24 indigenous plants of Burkina Faso. Journal of Food composition Analysis 10 205-207

10. Haeckel R (1981) Assay of creatinine in serum, with use of fuller's earth to remove interferents. Clin Chem 27: 179-183.

11. Hiimann G, Beyer G, Klin Z (1967) Biochemistry 5-93.

12. Iqbal A, Khalil IA, Ateeq N, Khan MS (2006) Nutritional quality of a important food legumes. Food Chemistry 97: 331-335.

13. Mfon IA, Item JA, Amabe A, Victor AF, Anozeng OI (2011) Effect of combined leaf extract of Vernoniaamygdalina(Bitter leaf) and Gongronema latifolium(utazi) on the panctreatic $ß$-cell of streptozotocin induced rat. British journal of medicine and medical Resource. 1: 24-34

14. Morebise FMA, Makinde JM, Olajide OA, Awe EO (2002) Antiinflammatory property of the leaves of Gongronemalatifolium. Phytotherapy Research Supplement 1: 75-77.

15. Ogundipe OO, Moody JO, Akinyemi TO, Raman A (2003) Hypoglycaemic potentials of methanolic extracts of selected plant foods in alloxanized mice. PIt. Foods Humanity nutrition 58: 1-7.

16. Soling D, Klenlneke J (1976) In: John wiley (ed.) Gluconeogenesis New York 369-462.

17. Sreejayan, Rao MN (1990) Nitric oxide scavenging by curcuminoids Proceedings of 42nd IPC Manipal 28-30

18. Dobbs S, Frank EI, Scon EC (2003) Enzyme activities on substrate. Journal of Basic Enzyme 4: 12-34.

19. Andullu B, Vardacharyulu NC (2001) Effect of mulberry leaves on diabetes. Int. J. Diabetes Dev Countries 21: 147-151.

20. Atawodi SE, Ogunbusola F (2009) Evaluation of anti-trypanosomal properties of four extracts of leaves, stem and root barks of Prosopisafricana in laboratory animals. Biokemistri 21: 101-108.

21. Atawodi SE (2005) Comparative in vitrotrypanocidal activities of petroleum ether chloroform, methanol and aqueous extracts of some Nigerian savannah plants. Afr J Biotechnol 4: 177-182. 
Citation: Ali Fredrick U, Ominyi MC, Nwankwo OVU, Ibiam UA, Ogbanshi ME (2015) Comparative Effects of Ethanolic Extract of Gongronema latifolium and Piper guineense on Blood Electrolytes in Ethanol Exposed Wistar Rats. Biochem Anal Biochem 4: 179. doi:10.4172/2161-1009.1000179

Page 5 of 5

22. Balkau B, Charles MA, Eschwege E (2000) Epidemiological discourse on new criteria on diabetes. MolecularEndocrinology 2: 229-234.

23. Bruce RD (1987) A confirmatory study of the up-and-down method for acute oral toxicity testing. Fundam Appl Toxicol 8: 97-100.

24. Chakrabarti S, Biswas TK, Rokeya B, Ali L, Mosihuzzaman M, et al. (2003) Advanced studies on the hypoglycemic effect of Caesalpinia bonducella $F$. in type 1 and 2 diabetes in Long Evans rats. J Ethnopharmacol 84: 41-46.

25. Deepak A, Anshu S (2008) Indigenous Herbal Medicines: Trial Formulations and Traditional Herbal Practices. Harishkar Publishers Distributor, Jaipur, India 440-444.

26. Dheer R, Bhatnagar P (2010) A study of the antidiabetic activity of Barleria prionitisLinn. Indian J Pharmacol 42: 70-73.

27. Dixon WJ (1991) Staircase bioassay: the up-and-down method. Neurosci Biobehav Rev 15: 47-50.

28. Djomeni PDD, Tedong L, Asongalem EA, Dimo T, Sokeng SD (2006) Hypoglycaemic and antidiabetic effect of root extracts of Cebiapentandra in normal and diabetic rats. Africa Journal Traditional Complementary Alternative Medicine. 3: 129-136.

29. Ezekwesili CN, Obidoa O, Nwodo OFC (2008) Effects of ethanol extract of Acalypha torta leaves on the lipid profile and serum electrolytes of rabbits. Niger Journal Biochemistry Molecule Biology 23: 15-19.

30. Florence NT, Theophile D, Desire DDP, Bertin V, Etienne D (2007) Antidiabetic activities of methanol-derived extract of Dorsteniapicta twigs in streptozotocininduced diabetic rats. Asian Journal Traditional Medicine. 2: 140-146.

31. Gholap S, Kar A (2004) Hypoglycaemic effects of some plant extracts are possibly mediated through inhibition in corticosteroid concentration. Pharmazie 59: 876-878.

32. Gnanong WF (2005) Endocrine Functions of the Pancreas and Regulation of Carbohydrate Metabolism. In: Review of Medical Physiology, Gnanong, W.F. (Ed.). McGraw Hill, New York, USA 333-355.

33. Gornall AG, Bardawill CJ, David MM (1949) Determination of serum proteins by means of the biuret reaction. J Biol Chem 177: 751-766.
34. Grover JK, Yadav S, Vats V (2002) Medicinal plants of India with anti-diabetic potential. J Ethnopharmacol 81: 81-100

35. Henry RJ (1974) Determination of Serum Creatinin. In: Henry RJ (ed.) Clinica Chemistry: Principles and Techniques, Harper and Row, London, UK. 525-530.

36. Jaiswal D, Rai PK, Watal G (2009) Antidiabetic effect of Withania coagulans in experimental rats. Indian J Clin Biochem 24: 88-93.

37. Kane MP, Abu-Baker A, Busch RS (2005) The utility of oral diabetes medications in type 2 diabetes of the young. Curr Diabetes Rev 1: 83-92.

38. Tamás L, Huttová J, Mistrk I, Kogan G (2002) Effect of Carboxymethyl ChitinGlucan on the Activity of Some Hydrolytic Enzymes in Maize Plants. Chemistry Papers 56: 326-329.

39. Tapsell LC, Hemphill I, Cobiac L, Patch CS, Sullivan DR, et al. (2006) Health benefits of herbs and spices: the past, the present, the future. Med J Aust 185: S4-24.

40. Ali FU, Ibiam UA (2014) phytochemical studies and gc-ms analysis ogongronema latifolium and piper guineense international journal of innovative reseach and development. 3: 108-115.

41. Tiku SC (2007) Piper guineense leaf extract on reproductive organ of male rats Journal of Natural Product 44: 78-81.

42. Ugochukwu NH, Babady NE (2002) Antioxidant effects of Gongronema latifolium in hepatocytes of rat models of non-insulin dependent diabetes mellitus. Fitoterapia 73: 612-618.

43. Ujowundu CO, Kalu FN, Nwaoguikpe RN, Okechukwu RI, Ihejirika CE (2015) The Antioxidative Potentials of G.latifolium on Diesel Petroleum Induced Hepatotoxicity. Journal of Applied Pharmaceutical Science 2: 90-94.

44. Ali FU, Ominyi MC, Ogbanshi ME (2015) Comparative evaluation of effect of Gongronema latifolium and Piper guineense ethanol extract against scavenging enzymes and marker of oxidative stress in ethanol induced liver injury in wista rats. International Journal Of Innovative Research and Development.volume 4: 61-71. 